ISSN 0258-7122

Bangladesh J. Agril. Res. 38(1): 41-48, March 2013

\title{
EFFECT OF SOIL AND FOLIAR APPLICATIONS OF ZINC AND IRON ON THE YIELD AND QUALITY OF ONION (Allium cepa L.)
}

\author{
A. P. TRIVEDI ${ }^{1}$ AND K.N. DHUMAL ${ }^{2}$
}

\begin{abstract}
A field experiment was carried out at the research farm of National Research Centre for Onion and Garlic, Manjari, Pune (Maharashtra), India during kharif season of 2004 and 2005 to find out the effect of application of zinc and iron and their different modes of applications on growth, yield, and quality of onion. There were 27 treatment combinations with $\mathrm{Zn}$ and Fe were applied either in the soil or as foliar spray with cow dung slurry/FYM/gibbrelic acid/amino acids/2,4$\mathrm{D}$ to onion. Application of $\mathrm{Zn}$ significantly increased the bulb weight (73.9 $\mathrm{g}$ ), bulb yield (45 t/ha) when applied with 2,4-D (3 ppm) as foliar spray. Zinc application significantly influenced the bulb quality and recorded the highest 'A' grade bulbs and the lowest poor quality ' $C$ ' grade bulbs when applied with $2,4-\mathrm{D}(81.9 \%)$ as foliar spray. The maximum medium ' $\mathrm{B}$ ' grade bulbs were obtained with the application of Fe with cow dung slurry $(11.4 \%)$.
\end{abstract}

Key words: Onion, zinc, iron, yield, quality.

\section{Introduction}

Onion (Allium cepa L.) is a versatile food source due to its unique flavour and odor. It adds taste to many dishes in the form of vegetables as well as spice. It's the unique ingredient of the dishes from the richest to the poor man's meal. Onions are rich in powerful sulphur-containing compounds that are responsible for pungent odors, and for many of health-promoting effects. It contains antiinflammatory, anti-cholesterol, anticancer, and antioxidant components, such as quercetin. India consumes, on an average, 40 lakh tonnes of onion a year and the projected imports of around 13,000 tonnes partly meet out from the countries like Iran, Oman, and Dubai (Anon., 2010) So, to meet the growing demand, concentrated efforts are needed to produce sufficient quantity and of high quality onions. With no scope for expansion in area under vegetable cultivation, future growth has to come from per se increase in output by finding the ways and means to enhance the productivity of onion through suitable agro-technologies that are within the reach of Indian farmers. One of the options is by using balanced nutrition and the supply of macro and micronutrients through the combination of both organic and inorganic sources. Plant growth regulators (PGRs) which enhance the growth and development of the plants are the potential sources to

${ }^{1}$ Directorate of Medicinal and Aromatic Plants Research, Boriavi, Anand, ${ }^{2}$ Deptt. of Botany, University of Pune, Pune-411007, India. 
supplement the nutritional requirement of the plants (Wareing and Phillips, 1982). Information regarding interactive effects of mineral nutrients, phytohormones and other bio-regulators on physiological processes, yield and quality of onion has not yet been established. Therefore, the present investigation was undertaken to find out the effect of zinc $(\mathrm{Zn})$ and iron $(\mathrm{Fe})$ application from different sources (organic manures, fertilizers and bio-regulators) on growth, yield and bulb quality of onion.

\section{Materials and Method}

The field experiments were conducted during kharif seasons of 2004 and 2005 at the research farm of National Research Centre for Onion and Garlic, Manjari, Pune, India. The average annual rainfall in both the years, of investigation was $669 \mathrm{~mm}$ and was fairly distributed from June to October. The maximum and minimum temperature during the experimental period was $17.6^{\circ} \mathrm{C}$ and $31.8{ }^{\circ} \mathrm{C}$, respectively. The details of experimental soils were medium black clay loam, high in $\mathrm{pH}(8.7)$, medium in organic carbon $(0.7 \%)$, low in available nitrogen (114 ppm N/ha) and phosphorus (53 ppm $\mathrm{P} / \mathrm{ha}$ ) and medium in available potassium (280 ppm K/ha) and initial status of zinc in FYM and cowdung slurry was $13 \mathrm{ppm}$ and $113 \mathrm{ppm}$ and iron in FYM and cowdung slurry was $22.31 \mathrm{ppm}$ and $4.18 \mathrm{ppm}$.

Pure seeds of onion variety Baswant-780 were collected from the National Research Centre for Onion and Garlic, Pune for conducting the present study. Nursery was prepared by using standard techniques. The experiments were conducted during kharif season. It was laid out in a randomized block design with three replications. There were altogether 27 treatment combinations with $\mathrm{Zn}$ and $\mathrm{Fe}$ from different sources applied as soil or foliar methods. Micronutrients $\mathrm{Fe}$ and $\mathrm{Zn}$ were added to the soil with FYM and cow dung slurry. They were also applied as foliar spraying with amino acid, giberrelic acid $\left(\mathrm{GA}_{3}\right)$ or 2, 4-D. Suitable surfactant was added to the solution to reduce surface tension. Multiplex (manufactured by Karnataka Agro Ltd.) was used as foliar spray to find out its efficacy on onion. Soil application of $\mathrm{Zn}$ and $\mathrm{Fe}$ was done at 15 days of transplanting (DAT), while foliar applications were given at 30, 45, and 60 of DAT.

The onion seeds were sown in line on well leveled, raised beds in the month of May every year. The raised beds were prepared and basal application of fertilizers was given according to the treatments designed. The drip laterals having discharge of 4 liters per hour were placed on raised beds. Healthy seedlings of 45 days' old were transplanted in the main field after removing upper one third portions of leaves to reduce the loss of water through transpiration. 


\begin{tabular}{ccc}
\hline Particular & Rate of application & Mode of application \\
\hline Cow dung slurry & $5 \mathrm{t} / \mathrm{ha}$ & Soil application \\
$\mathrm{Zn}$ & $10 \mathrm{~kg} / \mathrm{ha}$ & Soil application \\
$\mathrm{Fe}$ & $10 \mathrm{~kg} / \mathrm{ha}$ & Soil application \\
$\mathrm{Zn}$ & $1 \mathrm{~g} / \mathrm{l}$ & Foliar application \\
$\mathrm{Fe}$ & $1 \mathrm{~g} / \mathrm{l}$ & Foliar application \\
$\mathrm{FYM}$ & $20 \mathrm{t} / \mathrm{ha}$ & Soil application \\
$\mathrm{GA}$ & $50 \mu \mathrm{gml}$ & Foliar application \\
Amino acids & $1 \mathrm{~g} / \mathrm{l}$ & Foliar application \\
$2,4-\mathrm{D}$ & $3 \mu \mathrm{g} / \mathrm{ml}$ & Foliar application \\
Multiplex & $2.5 \mathrm{~m} / 1$ & Foliar application \\
RDF & $100 \mathrm{~kg} \mathrm{~N}, 50 \mathrm{~kg} \mathrm{P} \mathrm{O}_{5}$ and $50 \mathrm{~kg} \mathrm{~K}_{2} \mathrm{O}$ & Soil application \\
\hline
\end{tabular}

Note: Zinc was applied as $\mathrm{ZnSO}_{4} 7 \mathrm{H}_{2} \mathrm{O}, \mathrm{FeSO}_{4} 7 \mathrm{H}_{2} \mathrm{O}$.

The crop was fertilized with complex NPK fertilizer (19:19:19), and urea was applied to adjust the $\mathrm{N}$ requirement to meet the recommended doses of 100:50:50 NPK/ha for onion. The $50 \% \mathrm{~N}$ was added as basal and remaining $50 \%$ in two equal splits at an interval of 30 and 45 days after transplanting.

Proper care for weeding, intercultural operations, and plant protection measures were taken from transplanting to harvesting. Observations on bulb yield and quality were made from the selected tagged 10 plants for each treatment. The parameters on onion bulbs were recorded after harvesting and curing. The onion bulbs were harvested when the leaves turned yellow during the month of October and the bulbs were cured in the field for a week. The harvested bulbs were cleaned and tops were cut carefully. The bulbs were cured again under shade for 3-4 days. The yield and quality parameters were recorded from randomly selected 10 bulbs of each experimental plot. Statistical analysis was done by using standard techniques (Panse and Sukhatme, 1995).

\section{Results and Discussion}

The data on the yield and quality parameters as influenced by various treatments with micronutrients and their mode of applications in 2004 and 2005 ae presented in Table 1 and 2.

\section{Bulb yield}

The results revealed that the effect of zinc and iron along with organic manures, fertilizers, and bio-regulators significantly affected bulb weight, dry matter content in bulb, and bulb yield in both the years of experimentation (Table 1).

Application of $\mathrm{Zn}$ with 2,4-D produced significantly higher bulb weight (73.9 g) followed by Zn with FYM (73.4 g), and Fe with cow dung slurry (73.1 g) over control. However, dry matter content was higher with the combined application of $\mathrm{Zn}+\mathrm{Fe}$ with cow dung slurry (30.2\%) followed by comparable content with Fe with GA (28.4\%). Bulb yield (45 t/ha) was significantly superior to the application of $\mathrm{Zn}$ with 2,4-D followed by $\mathrm{Zn}$ with FYM and $\mathrm{Zn} / \mathrm{Fe}$ with cow dung. 
Table 1. Effects of soil and foliar applications of $\mathrm{Zn}$ and $\mathrm{Fe}$ on yield attributes and yield of onion.

\begin{tabular}{|c|c|c|c|c|c|c|c|c|c|}
\hline \multirow[b]{2}{*}{ Treatment } & \multicolumn{3}{|c|}{ Weight of bulb (g) } & \multicolumn{3}{|c|}{ Dry matter content $(\%)$} & \multicolumn{3}{|c|}{ Yield (t/ha) } \\
\hline & $\begin{array}{c}2004 \\
-05\end{array}$ & $\begin{array}{c}2005- \\
06\end{array}$ & Pooled & $\begin{array}{c}2004- \\
05\end{array}$ & $\begin{array}{c}2005- \\
06\end{array}$ & Pooled & $\begin{array}{c}2004- \\
05\end{array}$ & $\begin{array}{c}2005- \\
06\end{array}$ & Pooled \\
\hline \multicolumn{10}{|c|}{ Soil application with cow dung slurry } \\
\hline $\mathrm{Zn}$ & 72.2 & 71.2 & 71.7 & 12.3 & 13.4 & 12.8 & 41 & 43 & 42 \\
\hline $\mathrm{Fe}$ & 73.0 & 73.2 & 73.1 & 18.3 & 18.9 & 18.6 & 42 & 45 & 43 \\
\hline $\mathrm{Zn}+\mathrm{Fe}$ & 61.0 & 68.1 & 64.5 & 30.5 & 29.9 & 30.2 & 37 & 36 & 36 \\
\hline \multicolumn{10}{|c|}{ Soil application with RDF } \\
\hline $\mathrm{Zn}$ & 56.6 & 72.7 & 64.6 & 20.0 & 19.6 & 19.8 & 35 & 44 & 40 \\
\hline $\mathrm{Fe}$ & 56.9 & 68.7 & 62.8 & 15.5 & 14.5 & 15.0 & 34 & 37 & 36 \\
\hline $\mathrm{Zn}+\mathrm{Fe}$ & 61.3 & 71.2 & 66.2 & 20.5 & 20.2 & 20.3 & 38 & 41 & 39 \\
\hline \multicolumn{10}{|c|}{ Soil application with FYM } \\
\hline $\mathrm{Zn}$ & 73.5 & 73.3 & 73.4 & 21.0 & 19.1 & 20.0 & 42 & 45 & 44 \\
\hline $\mathrm{Fe}$ & 54.4 & 70.9 & 62.7 & 24.5 & 24.2 & 24.4 & 35 & 40 & 37 \\
\hline $\mathrm{Zn}+\mathrm{Fe}$ & 61.1 & 70.1 & 65.6 & 21.5 & 20.1 & 20.8 & 37 & 37 & 37 \\
\hline \multicolumn{10}{|c|}{ Foliar spray with water } \\
\hline $\mathrm{Zn}$ & 62.8 & 59.5 & 61.2 & 23.0 & 21.9 & 22.5 & 39 & 34 & 36 \\
\hline $\mathrm{Fe}$ & 53.6 & 67.3 & 60.5 & 21.5 & 21.4 & 21.5 & 35 & 35 & 35 \\
\hline $\mathrm{Zn}+\mathrm{Fe}$ & 56.7 & 55.7 & 56.2 & 23.0 & 22.1 & 22.6 & 36 & 33 & 34 \\
\hline \multicolumn{10}{|c|}{ Foliar spray with gibbrelic acid } \\
\hline $\mathrm{Zn}$ & 56.1 & 48.6 & 52.4 & 18.9 & 19.2 & 19.0 & 31 & 31 & 31 \\
\hline $\mathrm{Fe}$ & 49.9 & 50.1 & 50.0 & 27.9 & 29.0 & 28.4 & 27 & 31 & 29 \\
\hline $\mathrm{Zn}+\mathrm{Fe}$ & 39.6 & 57.5 & 48.5 & 22.0 & 19.9 & 21.0 & 23 & 33 & 28 \\
\hline \multicolumn{10}{|c|}{ Foliar spray with amino acids } \\
\hline $\mathrm{Zn}$ & 55.4 & 51.8 & 53.6 & 14.6 & 14.2 & 14.4 & 32 & 31 & 32 \\
\hline $\mathrm{Fe}$ & 53.8 & 56.2 & 55.0 & 22.3 & 21.3 & 21.8 & 25 & 24 & 25 \\
\hline $\mathrm{Zn}+\mathrm{Fe}$ & 60.6 & 60.4 & 60.5 & 20.5 & 20.3 & 20.4 & 24 & 25 & 25 \\
\hline \multicolumn{10}{|c|}{ Foliar spray with 2 4-D } \\
\hline $\mathrm{Zn}$ & 74.2 & 73.6 & 73.9 & 19.8 & 19.5 & 19.6 & 44 & 47 & 45 \\
\hline $\mathrm{Fe}$ & 60.3 & 50.8 & 55.5 & 17.9 & 17.7 & 17.8 & 27 & 29 & 28 \\
\hline $\mathrm{Zn}+\mathrm{Fe}$ & 40.2 & 47.0 & 43.6 & 26.9 & 26.7 & 26.8 & 24 & 29 & 27 \\
\hline \multicolumn{10}{|c|}{ Control treatments } \\
\hline $\mathrm{Zn}+\mathrm{FAS}$ & 58.4 & 45.4 & 51.9 & 22.0 & 21.9 & 22.0 & 34 & 28 & 31 \\
\hline FAS & 54.0 & 50.3 & 52.1 & 20.5 & 18.3 & 19.4 & 25 & 25 & 25 \\
\hline $\begin{array}{l}\text { Multiple } \\
\mathrm{x}\end{array}$ & 47.2 & 39.5 & 43.4 & 23.8 & 22.9 & 23.3 & 28 & 24 & 26 \\
\hline RDF & 39.9 & 38.7 & 39.3 & 23.0 & 22.6 & 22.8 & 27 & 35 & 31 \\
\hline FYM & 37.4 & 40.1 & 38.8 & 18.1 & 17.1 & 17.6 & 13 & 11 & 12 \\
\hline $\begin{array}{c}\text { Absolute } \\
\text { control }\end{array}$ & 28.0 & 27.9 & 27.9 & 11.0 & 10.4 & 10.7 & 10 & 11 & 10 \\
\hline $\operatorname{SEM}( \pm)$ & 0.9 & 1.4 & 4.1 & 1.1 & 1.6 & 0.9 & 1 & 1 & 2 \\
\hline $\begin{array}{c}\mathrm{CD} \\
(\mathrm{P}=0.05)\end{array}$ & 2.4 & 3.8 & 11.9 & 2.9 & 4.7 & 2.5 & 2 & 3 & 6 \\
\hline
\end{tabular}


Table 2. Effects of soil and foliar applications of $\mathrm{Zn}$ and Fe on quality attributes of onion.

\begin{tabular}{|c|c|c|c|c|c|c|c|c|c|c|c|c|}
\hline \multirow[t]{2}{*}{ Treatment } & \multicolumn{3}{|c|}{ 'A' grade bulb $(\mathrm{cm})$} & \multicolumn{3}{|c|}{ 'B' grade bulb (cm) } & \multicolumn{3}{|c|}{ 'C' grade bulb $(\mathrm{cm})$} & \multicolumn{3}{|c|}{ TSS (\%) } \\
\hline & 2004-05 & 2005-06 & Pooled & 2004-05 & 2005-06 & Pooled & 2004-05 & 2005-06 & Pooled & 2004-05 & 2005-06 & Pooled \\
\hline \multicolumn{13}{|c|}{ Soil application with cow dung slurry } \\
\hline $\mathrm{Zn}$ & 78.6 & 80.2 & 79.4 & 13.5 & 13.6 & 13.5 & 7.9 & 6.3 & 7.1 & 11.9 & 12.5 & 12.2 \\
\hline $\mathrm{Fe}$ & 80.5 & 81.1 & 80.8 & 11.5 & 11.4 & 11.4 & 8.0 & 7.6 & 7.8 & 11.8 & 11.7 & 11.7 \\
\hline $\mathrm{Zn}+\mathrm{Fe}$ & 69.8 & 70.2 & 70.0 & 21.8 & 20.7 & 21.2 & 8.5 & 9.1 & 8.8 & 11.9 & 12.5 & 12.2 \\
\hline $\mathrm{Zn}$ & 75.2 & 73.9 & 74.6 & 20.6 & 20.8 & 20.7 & 4.3 & 5.3 & 4.8 & 10.4 & 9.5 & 10.0 \\
\hline $\mathrm{Fe}$ & 75.1 & 78.8 & 76.9 & 18.1 & 16.6 & 17.4 & 6.8 & 4.6 & 5.7 & 10.7 & 11.5 & 11.1 \\
\hline $\mathrm{Zn}+\mathrm{Fe}$ & 72.2 & 72.2 & 72.2 & 18.3 & 17.6 & 17.9 & 9.6 & 10.2 & 9.9 & 10.7 & 10.8 & 10.7 \\
\hline \multicolumn{13}{|c|}{ Soil application with FYM } \\
\hline \multicolumn{13}{|c|}{ Foliar spray with water } \\
\hline $\mathrm{Zn}$ & 74.2 & 74.5 & 74.4 & 16.9 & 16.8 & 16.9 & 8.9 & 8.7 & 8.8 & 11.8 & 12.0 & 11.9 \\
\hline $\mathrm{Fe}$ & 71.7 & 71.3 & 71.5 & 19.8 & 19.6 & 19.7 & 8.5 & 9.0 & 8.8 & 9.9 & 9.8 & 9.8 \\
\hline $\mathrm{Zn}+\mathrm{Fe}$ & 70.7 & 69.2 & 69.9 & 19.2 & 18.8 & 19.0 & 10.2 & 12.1 & 11.1 & 9.6 & 9.5 & 9.6 \\
\hline \multicolumn{13}{|c|}{ Foliar spray with gibbrelic acid } \\
\hline $\mathrm{Zn}$ & 57.6 & 55.2 & 56.4 & 28.2 & 27.8 & 28.0 & 14.3 & 17.0 & 15.6 & 10.5 & 10.5 & 10.5 \\
\hline $\mathrm{Fe}$ & 72.3 & 70.9 & 71.6 & 18.1 & 16.1 & 17.1 & 9.7 & 13.0 & 11.3 & 10.0 & 11.0 & 10.5 \\
\hline $\mathrm{Zn}+\mathrm{Fe}$ & 68.2 & 67.1 & 67.6 & 24.3 & 23.6 & 23.9 & 7.6 & 9.3 & 8.5 & 9.8 & 10.5 & 10.2 \\
\hline
\end{tabular}


Table 2. Cont'd

\begin{tabular}{|c|c|c|c|c|c|c|c|c|c|c|c|c|}
\hline \multirow[t]{2}{*}{ Treatment } & \multicolumn{3}{|c|}{ ‘A’ grade bulb (cm) } & \multicolumn{3}{|c|}{ 'B' grade bulb (cm) } & \multicolumn{3}{|c|}{ 'C’ grade bulb $(\mathrm{cm})$} & \multicolumn{3}{|c|}{ TSS (\%) } \\
\hline & 2004-05 & 2005-06 & Pooled & 2004-05 & 2005-06 & Pooled & 2004-05 & 2005-06 & Pooled & 2004-05 & 2005-06 & Pooled \\
\hline \multicolumn{13}{|c|}{ Foliar spray with amino acids } \\
\hline $\mathrm{Zn}$ & 60.5 & 60.9 & 60.7 & 26.8 & 25.9 & 26.3 & 12.8 & 13.2 & 13.0 & 9.6 & 10.2 & 9.9 \\
\hline $\mathrm{Fe}$ & 70.3 & 69.8 & 70.0 & 23.5 & 22.7 & 23.1 & 6.3 & 7.5 & 6.9 & 9.9 & 10.0 & 10.0 \\
\hline $\mathrm{Zn}+\mathrm{Fe}$ & 62.8 & 63.7 & 63.2 & 22.7 & 22.3 & 22.5 & 14.6 & 14.0 & 14.3 & 9.6 & 9.6 & 9.6 \\
\hline \multicolumn{13}{|c|}{ Foliar spray with 2 4-D } \\
\hline $\mathrm{Zn}$ & 81.9 & 82.0 & 81.9 & 13.8 & 13.8 & 13.8 & 4.4 & 4.2 & 4.3 & 11.5 & 11.3 & 11.4 \\
\hline $\mathrm{Fe}$ & 73.4 & 74.1 & 73.7 & 18.5 & 18.4 & 18.4 & 8.1 & 7.5 & 7.8 & 11.5 & 11.0 & 11.2 \\
\hline $\mathrm{Zn}+\mathrm{Fe}$ & 74.1 & 74.1 & 74.1 & 16.3 & 16.0 & 16.1 & 9.7 & 9.9 & 9.8 & 9.5 & 10.7 & 10.1 \\
\hline \multicolumn{13}{|c|}{ Control treatments } \\
\hline Zn+FAS & 76.9 & 75.5 & 76.2 & 16.9 & 16.8 & 16.8 & 6.3 & 7.8 & 7.0 & 11.1 & 11.0 & 11.0 \\
\hline FAS & 51.2 & 49.1 & 50.2 & 32.1 & 30.4 & 31.2 & 16.7 & 20.5 & 18.6 & 11.8 & 11.5 & 11.7 \\
\hline Multiplex & 52.8 & 54.0 & 53.4 & 32.5 & 30.0 & 31.2 & 14.8 & 16.0 & 15.4 & 11.2 & 11.6 & 11.4 \\
\hline $\mathrm{RDF}$ & 57.3 & 57.4 & 57.3 & 26.8 & 27.5 & 27.2 & 16.0 & 15.1 & 15.6 & 9.9 & 9.9 & 9.9 \\
\hline FYM & 35.4 & 35.9 & 35.6 & 43.9 & 42.6 & 43.2 & 20.8 & 21.6 & 21.2 & 10.8 & 11.5 & 11.2 \\
\hline $\begin{array}{c}\text { Absolute } \\
\text { control }\end{array}$ & 23.5 & 23.6 & 23.6 & 36.3 & 35.9 & 36.1 & 40.3 & 40.5 & 40.4 & 9.4 & 9.0 & 9.2 \\
\hline $\operatorname{SEM}( \pm)$ & 0.8 & 0.6 & 0.6 & 1.6 & 0.3 & 0.8 & 2.0 & 0.6 & 1.0 & 0.2 & 0.3 & 0.3 \\
\hline $\mathrm{CD}(\mathrm{P}=0.05)$ & 2.4 & 1.8 & 1.6 & 4.6 & 0.9 & 2.1 & 5.8 & 1.7 & 2.8 & 0.6 & 0.8 & 0.7 \\
\hline
\end{tabular}


The increase in bulb weight might be due to improved growth and yield attributes as a result of positive influence of micronutrients and growth regulators. Similar findings were also recorded by Bahadur and Maurya. (2001) and Mandal et al. (2003). Addition of cow dung slurry, FYM and increase in soil micro flora might be responsible for improving the soil physical, physiological, and biological properties of soil. The integrated nutrient management showed superior performance towards yield improvements (Jayathilake et al., 2003 and Thapa et al., 2005). Auxin (2,4-D) and gibberellins both are involved in signal transduction pathways which then initiate the gene expression leading to stimulation in various activities involved in improvement of yield attributes and yield. The treatments of micronutrients, bio regulators along with organic manures might be responsible for increasing the chlorophyll content and thereby photosynthetic rate, which usually cause increase in the yield. Manipulation of source (leaf) and sink (bulb) relationship through the above treatments may be the principal reason for yield improvement.

\section{Bulb quality}

The bulbs were graded into three categories based on diameter viz., 'A' grade ( $\geq$ $4.5 \mathrm{~cm})$, 'B' grade $(2.5$ to $3.5 \mathrm{~cm})$, and $\mathrm{C}$ grade $(\leq 2.5 \mathrm{~cm})$ (Table 3$)$. The significantly higher value of ' $A$ ' grade bulbs was recorded with the application of Zn with 2,4-D (81.9\%) followed by $\mathrm{Zn}$ with FYM (81.8\%), and Fe with cow dung $(80.8 \%)$ compared to control $(23.6 \%)$. However, the lowest percentage of poor quality ' $\mathrm{C}$ ' grade bulbs were obtained with the application of $\mathrm{Zn}$ with FYM (3.5\%) followed by $\mathrm{Zn}$ with 2,4-D (4.3\%) and $\mathrm{Zn}$ with RDF (4.8\%) compared to control which recorded the highest number of poor quality ' $\mathrm{C}$ ' grade bulbs (40.4\%). The medium ' $\mathrm{B}$ ' grade bulbs were observed with the application of $\mathrm{Fe}$ with cow dung slurry (11.4\%) whereas, the highest result with was FYM alone (43.2\%) followed by control (36.1\%).

Total soluble solids (TSS) of the onion bulbs recorded with the application of $\mathrm{Zn}$ and $\mathrm{Zn}+\mathrm{Fe}$ with cow dung slurry $(12.2 \%)$ were significantly higher than in control (9.2\%). Similar findings were also recorded by Lal et al. (2002). The improvement in TSS content in treated bulbs due to bio-regulators and micronutrients might be attributed to enhance metabolic processes involved in biosynthesis of total soluble solids such as carbohydrates, organic acid, amino acids and other inorganic constituents. The bio-regulators had quite influencing role on translocation of different types of total soluble solids from leaves towards the bulbs (Wareing and Phillips, 1982). The micronutrients and bio-regulators when act in combination, they have profound effect on of carbohydrates, starch, sugars, fructose, proteins, etc. The enhancement in all such bio-chemical constituents had caused an increase in TSS and dry matter. Both the bulb quality parameters are important in processing, storage and export. 
Thus, it can be concluded that the zinc application with 2, 4-D as foliar spray had remarkable effects and increased bulb weight, bulb yield, and the 'A' grade bulbs of onion in both the years of experimentation.

\section{References}

Bahadur, A. and V.N. Maurya. 2001. Effect of $\mathrm{GA}_{3}$ and foliar feeding of urea on bulb production of onion (Allium cepa L.). Vegetable Science 28(1): 90-91.

Jayathilake, P. K. S., I. P. Reddy, D. Srihari, R. Reddy and G. Neeraja 2003. Integrated nutrient management in onion (Allium cepa L.). Tropical Agriculture Research 15: 1-9.

Lal S., A. C. Yadav, J.L. Mangal, A. Singh and V. K. Batra. 2002. Effect of FYM and irrigation levels on growth and yield of onion cv. Hisar-2. Haryana J. Hort. Sci. 31(3\&4): 256-258.

Mandal, S., Subhadeep Nath, P. Ghanji and N. Sukala. 2003. Effect of doses and methods of application of $\mathrm{GA}_{3}$ and NAA on growth and yield of onion ((Allium cepa L.). Environment and Ecology 21(3): 568-571.

Panse, V. G. and P. V. Sukhatme. 1995. Statistical methods for agricultural workers. Indian edition, Hans Publishers, Bombay.

Thapa, U. M. K. Patti, S. R. Chattopadhyay and A. R. Mandal. 2005. Growth and seed yield of onion (Allium Cepa L.) cv. Sukh sagar as influenced by growth regulators and bulb size. Research on crops 6(1): 55-57.

Wareing, W. R. and I. D. J. Phillips. 1982. Growth and differentiation in Plants. In: $3^{\text {rd }}$ edition, Pergoman Press, Elmsford, New York. 